\title{
School Factors and Teacher Burnout: A Perception
}

\author{
John Matiang'i, Lazarus Ndiku Makewa, Elizabeth Role \\ University of Eastern Africa, Baraton, Eldoret, Kenya \\ Email: Johnoma2000@yahoo.com,ndikul@gmail.com,emrole716@yahoo.com
}

How to cite this paper: Matiang'i, J., Makewa, L.N. and Role, E. (2016) School Factors and Teacher Burnout: A Perception. Open Access Library Journal, 3: e2996.

http://dx.doi.org/10.4236/oalib.1102996

Received: October 23, 2016

Accepted: November 21, 2016

Published: November 24, 2016

Copyright $\odot 2016$ by authors and Open Access Library Inc.

This work is licensed under the Creative Commons Attribution International

License (CC BY 4.0).

http://creativecommons.org/licenses/by/4.0/

\begin{abstract}
This study attempted to determine teacher perception on school factors affecting their work. In order to attain this determination, the following variables were used: administrative support, workload, staff development, student discipline, salary, school facilities, and role expectation. One hundred and sixty eight (168) teachers participated in this study. Major data collection tools were questionnaires. The validity was determined by the expert use of experienced researchers from the university of Eastern Africa, Baraton. Internal consistency of the data obtained from this research instruments was determined by the use of Cronbach's coefficient Alpha. The reliability coefficient for each section of the questionnaire addressing different variables was computed based on the responses given by the teachers from the two schools which were involved in a pilot study. The coefficient that determined the reliability of the instrument for this study was 0.811 far above the 0.6 , thus the instrument was reliable for data collection. All statistical techniques selected were done by the use of the statistical package for social science (SPSS) program. The results indicate that there is minimal administrative support from the administration, and teachers are overloaded, and staff development has been sparingly done, and student discipline, though not a big problem in schools should be improved. Teachers indicated that there was need to provide facilities which give extra energy to the teaching and learning process.
\end{abstract}

\section{Subject Areas}

Sociology

Keywords

Teacher, Burnout, Perception, Staff Development, Student Discipline, School Facilities

\section{Introduction}

\subsection{Teacher Burnout and Administrative Support}

Administrative support is the help given to a teacher by the administrators in order for 
the teacher to execute his/her day operations within the school. [1] has pointed out in his research that stress is a major factor in teacher burnout. The stress is hereby engendered among others interactions of a teacher with eruptive parents, administrators and colleagues.

\subsection{Teacher Burnout and Work Load}

[1] observes that one of the reasons why most teachers in Kenya are planning to leave teaching when an opportunity arises is increased workload. To address workload in schools, the following measures can be applied.

- Innovative timetabling

- Effective use of I.C.T.

- Effective use of support staff

- Staffing schools with enough teachers

- Change on staffing procedures

- Student guidance and classroom management

- Management and administrative practices

- Employment of additional teachers by the Boards of Management

- Using non-teaching staff to monitor student attendance and other non-teaching duties

- Limiting meetings to avoid wastage of the class time

- Balancing administrative duties among teachers

\subsection{Burnout and Staff Development}

Staff development, also referred to as professional development, is an important factor for effective productivity in the workplace. According to [2], an aim of Professional Development is to empower teachers with new knowledge and skills, and to confirm that current practices and interpretations of education policy and procedure are correct. [3] contends that staff development programmes act as a catalyst for teachers' effectiveness in their daily routine. It is a potent means of updating teachers' skills and knowledge for improving instruction and learning. According to findings of their study in Nigeria, teachers who participated in staff development programmes were more effective in their job performance than those who did not, in terms of knowledge of subject matter, classroom management, teaching methods and evaluation of student's work. This brings to view importance of teachers' professional development in order to increase their levels of productivity in terms of the highest levels of students' achievement.

Teachers can be helped to identify their development needs in a number of ways, including self-review, informed discussions with the principal or through individual appraisal interview. The process of development of teachers can be through observation, reflection, planning and action. [4] further considers lifelong learning as a sense-making process of constructing, filtering, framing and creating an effective teacher. For effective staff development, it is necessary to work flexibly and eclectically in order to meet the demands of each situation. An effective staff development process is supportive of 
the individual and will benefit the school, hence, a well-organized staff development process in a school will alleviate teacher burnout.

\subsection{Teacher Burnout and Student Discipline}

Student discipline is primarily projected at controlling the students' actions and behaviors. In this regard, [5] states that putting up a system of rules and regulations means students having to abide by rules and other behavioral strategies meant to regulate them. A consequence of breaking these rules is also spelled out clearly. Acts of corporal punishment, detention, suspension and expulsion are commonly applied in most schools to reduce indiscipline in students. Disruptive and antisocial behavior of students interferes with leaning, diverting administrative time and contributing to teacher burnout.

As [6] point out, failure to deal effectively with these disruptive and antisocial students will contribute to poor individual, school, and community outcomes. To reduce teacher burnout due to student discipline, schools should develop appropriate strategies and interventions for students. This, according to [5], should include:

1) Establishment of a school-wide behavior support system to involve; school rules, teaching appropriate behavior, intervention plans, positive reinforcement for behavior, teaching of social skills.

2) Assisting students in the development of resiliency skills, which include; developing supportive relationships with students; maintaining positive and high expectations for all students; providing opportunities for students to participate and contribute; providing growth opportunities for students; ensuring that all students have a caring adult in their lives (mentoring); teaching students that they are capable and that they have strengths; providing opportunities for self-assessment and self-reflection; providing opportunities to work with other students (cooperative learning); school counseling and teacher advisory systems.

3) Assisting students in developing pro-social skills (to enable them function socially in the society) such as, anger management, conflict resolution, empathy etc.

4) Developing administrative procedures and policies for dealing with behavioral concerns. This will involve the school principal, teacher on duty, class teacher or boarding master. Some of these strategies will include; suspension policies; teacher proactive time out; daily communication; debriefing; family group conferencing.

\subsection{Teacher Burnout and Salary}

As noted by [7], teachers earn considerably less than other college-educated workers and that their salaries are unlikely to keep pace with high inflation rates. [1] found out from his research that among the causes of teacher burnout in Kericho municipality, was inadequate salaries, which compelled some teachers to take other jobs after school, engaged in secondhand clothe business, moonlighting, teaching computer classes in town and some operating public transport business, hence having less time for school related tasks, consequently leading to a decline in quality of education. 
According to the survey of public school teachers conducted by the national education association in 1983 in America, four out of ten teachers hold second jobs outside of education during the school year and some assume extra paid duties to compensate for the level of salaries offered to them [8].

Salary is often indicative of the value society places on the profession. In Kenya, holiday tuition is not allowed by the government but the teachers have offered paid up tuition in the guise of covering the syllabus, just to raise an extra coin to top up their salaries. World over, burnout on teachers has been projected in teachers' strikes that have caused perpetual interruption to learning. What the teachers protest for is almost the same across the board; better wages, working conditions and pension. In South Africa, the South African Democratic Teachers Union (SADTU) has led South African teachers out of class seven times up to 2011, to demand for better wages and better working conditions. The same situation has been observed in the UK, in Canada, in Chicago, Denmark, Mexico, Tanzania and in Kenya, with the Kenyan teachers going on strike ten times between the year 1962 and 2009, mostly for not being paid the amount of money promised to them by government officials. These strikes have had far reaching consequences on the children and mostly those in the public schools, as teachers break off from normal lessons for long while children in the private schools are learning.

\subsection{Teacher Burnout and School Facilities}

The physical characteristics of a school have a variety of effects on teachers, students and the learning process. Poor lighting, noise, inconsistent temperatures, poor ventilation and poor maintenance lead to poor health among students and teachers [9] [10]. Size of classrooms, library facilities, staffroom, the kind of furniture and toilets are facilities that need to be put in place for the teacher to work better. Often times, teachers are forced to use their money to purchase basic supplies like textbooks, chalk, writing materials and photocopying of revision materials for students. This has become a stress to the teachers and mostly when efforts to have the administration address these shortages are not achieved.

A report from the National Clearinghouse for Education and Families [11] shows that lack of resources can contribute to teachers' job dissatisfaction. In interviews with New York City public school teachers, a large percentage of new teachers said they did not have basic supplies and had to use their own money to purchase them.

\subsection{Teacher Burnout and Role Expectation}

Role expectation means that which is expected of a teacher to whom some given work or task is assigned. It is how others believe one should act in given situations. In examining organizational factors that contribute to job stress, numerous studies have identified role conflict and role ambiguity as important contributors.

In their study of role stress in educational organizations [12] found out that where high levels of role conflict and role ambiguity were present, teachers experienced high levels of emotional exhaustion and fatigue as well as negative attitudes towards stu- 
dents. [8] noted the lack of control or autonomy in one's job also contributed to burnout. Control in this context involves the teacher's perception of his influence on decision making, regarding such issues as work scheduling and the development of policies that directly affect his work environment. With high role expectations that are poorly defined, teachers are likely to get stressed and burned out. Involving them in planning policies and job programmes that work well with them is appropriate.

As pointed out by [1] it is only when specific causes of burnout are identified that steps can be taken to reduce their effect. This is because at times many of the conditions which determine teacher effectiveness lie outside their control [13]. According to [13] a behavioral definition of burnout and defines it as a condition in which teachers remain as paid employees but stop functioning as professionals. They go through the motions of teaching with no emotional commitment to the task and no sense of efficacy. These kinds of teachers have come to believe that what they can do will make no significant difference in the lives of their students and see no reason to continue caring or expending any serious effort to the students.

Burnouts remain in teaching as "strong insensitive" who are able to cope with the debilitating problems faced by their students and the negative conditions of work in dysfunctional bureaucracies because they no longer take their failures as a sign of any personal inadequacies. They have become detached job-holders who feel neither responsible nor accountable for students' behavior, learning, or anything else. Their only goal is to do the minimum required to remain employed [13]. This, though may appear contrary with some teachers who, out of their commitments and heavy workloads, are stressed and burned out but have not translated or transferred the same to their jobs.

\section{Method}

\subsection{Population and Sampling Techniques}

The study population comprised of all the 168 teachers employed by Teachers Service Commission teachers in the 21 public secondary schools in Borabu District. All teachers were taken for the study since the issues affecting academic results are not one man issue; all teachers in a school contribute in one way or the other towards good or poor academic performance. The population was also small to be sampled so it was taken intact.

\subsection{Research Instruments}

Four point scale questionnaire was used for collecting data. The selection of this tool was guided by the nature of data to be collected, the time available as well as the objectives of the study. The researchers were mainly concerned with views, opinions, perceptions, feelings and attitudes on the phenomena to be investigated and such information would best be collected through the use of questionnaires and interview schedules [14]. Questionnaires were used because the study was concerned with variables that might not be directly observed such as views, opinions, perceptions feelings and attitudes of the respondents. Besides, the identification of respondents was taken care of while ga- 
thering information in the study by the use of the questionnaire. The target population in this study was largely literate thus very much unlikely to have difficulties responding to questionnaire items. The questionnaire was modeled on a Likert four point scale numbered as $4=$ Agree, $3=$ Tend to Agree, $2=$ Disagree and $1=$ Tend to Disagree. It was subdivided into three sections, that is, section one-demographic data, Section two-attitude towards the teacher's job and section three-perceived causes of burnout.

\subsection{Validity}

Validity is defined as the degree to which a test measures what it is supposed to measure, while on the other hand reliability of a research instrument measures the extent to which the instrument yields the same results on repeated trials. The tendency towards consistency found in repeated measurements is the one referred to as reliability [14].

In order to maintain consistency and relevance to the problem, questionnaire items were formulated around the aspects of the problem being investigated. Questions in the teachers' questionnaire were carefully selected so as to bring out information on the emotional condition of teachers, their feelings and attitudes towards their work, their administrators and the students. The questionnaire further brought out the causes of the stress and burnout to these teachers. To establish the validity of the questionnaire, the researchers consulted with other professors in the department of Education, Curriculum and Teaching of the University of Eastern Africa Baraton before it was ready to be administered.

\subsection{Reliability of the Instruments}

All instruments used in this study were tested for reliability. That is if they had the ability to yield the same results consistently when repeated measurements would be taken under the same conditions [14]. A pilot study was conducted in two Secondary Schools in Masaba North District. These schools were selected for the pilot study because they are in the neighbouring district to Borabu District where the research was done. Internal Consistency of the data obtained from the research instruments was determined by the use of Cronbach's coefficient Alpha. The reliability coefficient for each section of the questionnaire addressing different variables was computed based on the responses given by the teachers from the two schools. The coefficient that determined the reliability of the instrument for this study was 0.811 far above the 0.6 and thus the instrument was reliable for data collection.

\subsection{Data gathering Procedures}

Data collection was carried out by the use of questionnaires that were prepared by the researchers. Permission was obtained from the research and ethics committee, University of Eastern Africa Baraton, which consequently assisted in obtaining permission from the National Council for Science and Technology of the Ministry of Higher Education, Science and Technology to proceed with data collection for the research. The researchers subsequently started collecting data from the concerned teachers in all pub- 
lic secondary schools in Borabu District. Each individual school was visited by the researchers asking assistance from the school principal or deputy principal to assemble the teachers for the distribution of the questionnaires. After introduction the researchers requested the teachers to fill the questionnaire, assuring them that their responses were purely for the purpose of the research and would be treated with strict confidence.

The researchers were allowed to administer the questionnaires to the teachers who were given time to fill them in. All questionnaires were filled and returned to the researcher on the same day in all schools visited. A total of 187 questionnaires were filled by the teachers.

When filling the questionnaire, the respondents were required to rate the questions on the questionnaire using the Likert scales- four point scale in which the interval between the points on the scale are assumed equal and are used to register the extent of agreement or disagreement with a particular statement of an attitude, belief or judgment. This also utilizes scales that examine quality [15].

\subsection{Statistical Treatment of Data}

The mean and standard deviation was used to give a description of the independent and dependent variables. All statistical techniques selected were done by the use of the statistical package for social science (SPSS) program.

\section{Results}

This study attempted to determine teacher perception on school factors affecting their work. The following variables were used for this determination.

a) Administrative support

b) Workload

c) Staff development

d) Student discipline

e) Salary/wages

f) School facilities

g) Role expectation

Each table below indicates the perception of the teachers on each of the above variables.

In evaluating how teachers rated the support from their principals, some sub variables were used. The teachers (respondents) used the scale Disagree-Tend to disagree-Tend to agree and agree to indicate how they rated the principal's support. The study found out that the aspect of the principal's communicating important information to the teachers in time scored the highest mean of 2.9027. Though they are averagely rated, it shows that most of the Head teachers in Borabu Public Secondary schools do communicate to important issues with their teachers in time. But it also indicates that there are some principals who need to improve in the way and speed at which information should be relayed to their teachers (Table 1).

The researcher correlated the response in the sub-variable discussed above with that 
Table 1. Perception of teachers on administrative support.

\begin{tabular}{llc}
\hline & Mean & Std. Deviation \\
\hline I feel the administration in this school often interfere with my work. & 1.9786 & 1.11180 \\
Teachers in this school trust the principal. & 2.5134 & 1.05931 \\
Teachers in this school are suspicious of most of the principal's actions & 2.1979 & 1.10151 \\
I feel the principal in my school typically acts in the best interest of the teachers. & 2.6043 & 1.21531 \\
I feel the principal in my school shows concern for the teachers. & 2.7594 & 1.14105 \\
I feel I can strongly rely on the principal of this school. & 2.7380 & 1.15507 \\
The principal often does not tell teachers what is going on in the school. & 2.1818 & 1.19995 \\
Teachers in my school are well involved in planning school activities and functions. & 2.4920 & 1.15642 \\
My school has a positive environment and a conducive climate for me to work in & 2.8075 & 1.07531 \\
Administration rules in this school enable authentic communication. & 2.7219 & 1.08643 \\
Administrators in my school do set a good example by working hard. & 2.8075 & 1.10976 \\
In my school the principal communicates important information to the staff in time. & 2.9027 & 1.18470 \\
Administrative rules in this school are used to punish teachers. & 1.9091 & 1.00390 \\
Administration rules in this school are a guide to solution rather than rigid procedures. & 2.8065 & 1.09799 \\
In this school the authority of the principal is used to undermine teachers. & 1.7861 & 1.05607 \\
Teachers in my school are assigned responsibilities with no strings attached. & 2.6578 & 1.16420 \\
Valid N (listwise) & & \\
\hline
\end{tabular}

\begin{tabular}{ccc}
\hline & N & Mean \\
\hline Administrative Support & 187 & 2.7973 \\
Valid N (listwise) & 187 & \\
\hline
\end{tabular}

stated negatively, that "the principle often does not tell teachers what is going on in the school." This was rated with a mean of 2.1818 , to mean that most of the teachers tended to disagree to that sub-variable.

The study also found out that most principals do not involve their teachers in planning school activities and functions, (mean of 2.4920). When members of any organization are not involved in planning and running the activities of the organization, most of them will take passive positions, some will feel neglected or not valued, hence, withdrawing their efforts to make the organization succeed [16]. The involvement of the teachers by the principals in any school will contribute a lot towards its success.

On the climate set by the principals in their schools, more than a half of the respondents agreed that their schools had positive environment to work in. This was shown by a mean of 2.8075 . They also tended to agree $($ mean $=2.7219)$ that administrative roles in their schools enable authentic communication and that the rules are a guide to solutions rather than rigid procedures (mean $=2.8065$ ). The principal sets the school's organizational climate, which will positively or negatively affect the teacher's self-efficacy [16]. 
With this research showing an average positive response towards administrative support given to the teachers (General mean $=2.7973$ ), it means that there are nearly the same number of teachers/respondents who are not contented with the support given to them by their principals.

Table 2 shows the perception of teachers on workload.

It is noted from the above table that the teachers in Borabu public secondary schools rated above average the issue of their departments requiring more teachers to ease the workload (mean $=3.3209$ ). This shows that there are departments that need teachers or are badly under staffed. Teachers desire to have an impact in the classroom and the risk of burnout escalates when too many non-instructional duties and an overload of responsibilities are the norm of the day.

The study also notes that majority of teachers (mean $=2.7487$ ) did not have enough time to plan their lessons due to heavy work load. This was an indicator that most teachers were going to school to teach unprepared. Respondents with a mean of 2.9679 felt weary and worked up at the end of their work day. Others felt that their jobs interfered with their life (mean $=2.5134$ ) and yet others (mean $=2.4118$ ) dreaded going to school due to the workload on their side. Majority of the teachers indicated that they were not tired with their students (mean $=1.6043$ ). This indicated that they had their students at heart though they were weary with their job.

The researchers noted that the teachers who were contemplating to leave their stations due to the heavy work load (mean $=1.9465)$ felt tired with their jobs (mean $=$ 1.9144). With a general mean of 2.4165 , the aspect of work load is rated slightly below average in causing teacher burnout in Borabu District secondary schools.

Table 3 will indicate perceptions of Teachers on Staff Development.

Table 2. Perception of Teachers on Workload.

\begin{tabular}{llc}
\hline & Mean & Std. Deviation \\
\hline I dread going to school due to the workload on my side. & 2.4118 & 1.12950 \\
I seriously feel like leaving this school due to the heavy workload. & 1.9465 & 1.11554. \\
In this school my workload is unevenly distributed so it piles up. & 2.3209 & 1.22858 \\
I feel that my job interferes with my family life. & 2.5134 & 1.1656 \\
I feel I don't have enough time to plan my lessons due to the heavy workload. & 2.7487 & 1.17131 \\
I feel I am tired with my job. & 1.9144 & 1.02294 \\
My department needs more teachers to ease the workload. & 3.3209 & 0.97481 \\
I am tired with some of my students. & 1.6043 & 1.02840 \\
I feel weary and worked up at the end of my work day. & 2.9679 & 1.07215 \\
Valid N (listwise) & & \\
\hline
\end{tabular}

\begin{tabular}{cccc}
\hline & $\mathrm{N}$ & Mean & Std. Deviation \\
\hline Workload & 187 & 2.4165 & 0.74434 \\
Valid N (listwise) & 187 & & \\
\hline
\end{tabular}


Table 3. Perception of Teachers on Staff development.

\begin{tabular}{|c|c|c|c|}
\hline & & Mean & Std. Deviation \\
\hline \multicolumn{2}{|c|}{ I feel confident that I have the skill to perform my duties. } & 3.9198 & 0.32624 \\
\hline \multicolumn{2}{|c|}{$\begin{array}{l}\text { My school Impresses professional development as a way of increasing } \\
\text { the skill level of teachers. }\end{array}$} & 2.78071 & 0.09252 \\
\hline \multicolumn{2}{|l|}{ I feel frustrated at work. } & 1.8610 & 1.09344 \\
\hline \multicolumn{2}{|c|}{$\begin{array}{l}\text { Workshops and seminars for the various subjects are often arranged in } \\
\text { my school to boost my knowledge and skills. }\end{array}$} & 1.7326 & 1.04889 \\
\hline \multicolumn{2}{|c|}{$\begin{array}{l}\text { The people I work with and my students make me feel like I am of vital } \\
\text { importance to the school. }\end{array}$} & 3.0802 & 0.98864 \\
\hline \multicolumn{2}{|c|}{ I feel I am supported with whichever materials I need for teaching. } & 2.6203 & 1.13602 \\
\hline \multicolumn{2}{|c|}{ Collegiality is so much cherished by all in my school. } & 2.4545 & 1.14150 \\
\hline \multicolumn{2}{|l|}{ I feel alienated at work. } & 1.7326 & 1.01767 \\
\hline \multicolumn{2}{|c|}{ Teachers in my school work as a team to ensure students achievement. } & 3.0802 & 0.84177 \\
\hline \multicolumn{2}{|c|}{ There is much professional and administrational growth in my school. } & 2.5829 & 1.05613 \\
\hline \multicolumn{4}{|l|}{ Valid N (listwise) } \\
\hline \multicolumn{4}{|c|}{ Descriptive Statistics } \\
\hline & Mean & \multicolumn{2}{|c|}{ Std. Deviation } \\
\hline Staff Development & 2.8658 & \multirow{2}{*}{\multicolumn{2}{|c|}{0.60465}} \\
\hline Valid N (listwise) & 187 & & \\
\hline
\end{tabular}

Looking at the table above, it is conspicuous that the teachers feel confident that they have the skills to perform their duties (mean $=3.9198$ ) and they also feel that their schools do not so much impress professional development as a way of increasing the skills they have $($ mean $=2.78017)$. This means that if the teachers are not improved professionally by being given refresher courses, seminars and workshops, the skills one possesses will get outdated [17]. This is why [18] observes that teachers need to feel successful and happy about themselves and their abilities before they can empower their students to feel the same.

While most of the respondents felt appreciated by their colleagues and their students at school (mean $=3.0802$ ), collegiality was not so much embraced in many schools (mean $=2.4545)$. But when it means that they have to come together to work for the betterment of the child they have no otherwise (mean $=3.0802)$. Staff development is rated well by the respondents (mean $=2.8658$ ).

Table 4 shows teachers' perception on Student discipline.

This study observed that many of the students in these schools were not well behaved. This was supported by a mean of 1.93 noted from the negative response upon the sub variable "students in my school are well behaved even when the teachers are not watching them". It was also noted that a good number of teachers praised their students more often than they scolded them (mean $=2.8824$ ) and that most students respected teachers, mean $=2.7219$. In general, it is observed that most of the respondents rated 
Table 4. Teachers' perception of Student discipline.

\begin{tabular}{|c|c|c|c|}
\hline & & Mean & Std. Deviation \\
\hline \multicolumn{2}{|c|}{ Most students in my school understand why they are in the school. } & 2.3690 & 0.94908 \\
\hline \multicolumn{2}{|c|}{$\begin{array}{l}\text { Students in my school are well behaved even when the teachers are not } \\
\text { watching them. }\end{array}$} & 1.9305 & 0.89831 \\
\hline \multicolumn{2}{|c|}{$\begin{array}{l}\text { Most students could do their work even if the teacher stepped out of the } \\
\text { classroom. }\end{array}$} & 2.1230 & 0.91631 \\
\hline \multicolumn{2}{|c|}{ In my school students are often sent home due to discipline cases. } & 2.5455 & 0.91688 \\
\hline \multicolumn{2}{|c|}{$\begin{array}{l}\text { The guidance and counseling department in my school is always occupied } \\
\text { with indiscipline cases. }\end{array}$} & 2.3797 & 1.09260 \\
\hline \multicolumn{2}{|c|}{ Students in my school respect the teachers. } & 2.7219 & 0.93768 \\
\hline \multicolumn{2}{|c|}{ In my school teachers praise students more often than they scold them. } & 2.8824 & 0.90224 \\
\hline \multicolumn{2}{|c|}{ I can handle discipline cases in my school with little or no interference. } & 2.7701 & 0.97582 \\
\hline \multicolumn{2}{|c|}{ Students in this school care about each other. } & 2.3048 & 0.94364 \\
\hline \multicolumn{2}{|c|}{ Teachers in this school trust their students. } & 2.2941 & 0.92406 \\
\hline \multirow[t]{2}{*}{ Valid N (listwise) } & & 187 & \\
\hline & Mean & \multicolumn{2}{|c|}{ Std. Deviation } \\
\hline Student Discipline & 2.4471 & \multicolumn{2}{|c|}{0.58561} \\
\hline Valid N (listwise) & 187 & & \\
\hline
\end{tabular}

the issue of students discipline as not good in their schools (mean $=2.4471)$.

Table 5 is a reflection of the teachers' perception on salary.

From Table 5 it is observed that a big number of teachers disagreed that they are well paid by their employer (mean $=1.2193$ ). This was also evident with the sub variable that they felt they were in conflict with people they had borrowed money from every month (mean $=2.7380$ ). [19] talks about teachers being among the lowest paid professionals in many countries the study found out that the work the teachers do was not commensurate with what they were paid as salary (mean $=1.2193$ ). This is why [7] observed that teachers who leave college are ill prepared of the ups and downs they immediately encounter as they get to the field. Those who enter teaching can expect to be underpaid, undervalued and over worked [19].

Looking at Table 5 below, the variations towards the disagreement of the sub variables used here is clearly evident that the respondents rated highly the problem of salaries.

A mean of 1.2941 is observed on teachers who disagree that their salary meets their needs, while a big percentage of the respondents (mean $=3.3636$ ) agree that the salaries in their job groups does not tally with that of others in the same job group elsewhere. This is a factor that has made teachers to leave their jobs for other well-paying jobs elsewhere or even moving out of the country for greener pastures.

Teachers' strikes in the country and in the neighboring countries as experienced in 
Table 5. Teachers' perception on Salary/ Wages.

\begin{tabular}{|c|c|c|c|c|c|}
\hline \multicolumn{6}{|c|}{ Descriptive Statistics } \\
\hline & & & & Mean & Std. Deviation \\
\hline \multicolumn{4}{|c|}{ My salary adequately meets my needs. } & 1.2941 & 0.69105 \\
\hline \multicolumn{4}{|c|}{ I feel I am in conflict with people I have borrowed money every month. } & 2.7380 & 1.08301 \\
\hline \multicolumn{4}{|c|}{ I feel I am well paid with my employer. } & 1.2193 & 0.59573 \\
\hline \multicolumn{4}{|c|}{ I feel my salary is commensurate with the work I do at school. } & 1.2193 & 0.53887 \\
\hline \multicolumn{4}{|c|}{$\begin{array}{l}\text { The salary in my job group does not tally with that of others in the same } \\
\text { job group elsewhere. }\end{array}$} & 3.3636 & 1.15766 \\
\hline \multicolumn{4}{|l|}{ Valid N (listwise) } & 187 & \\
\hline \multicolumn{6}{|c|}{ Descriptive data } \\
\hline & $\mathrm{N}$ & Minimum & Maximum & Mean & Std. Deviation \\
\hline Salary/Wages & & 1.00 & 3.40 & 1.5262 & 0.51422 \\
\hline Valid N (listwise) & 187 & & & & \\
\hline
\end{tabular}

the recent past to pressurize the government to improve their salaries and allowances is prove that they (teachers) are not happy with the kind of salaries paid to them. While studying on the anomalies associated with the status of teachers [20] made an observation that teaching seems to have more than its share of status anomalies. It is honored and disclaimed, praised as "dedicated service" and lampooned as "easy work", it is permeated with the rhetoric of professionalism, yet features incomes below those earned by workers with considerably less education. Making an observation from a survey carried on public school teachers by the National education Association in 1983 in America, [7] found that four out of ten teachers held second jobs outside of education during the school year and some assume extra paid duties to compensate for the level of salaries offered to them. This is evident what the principals said about the issue of students paying for holiday tuition which has been changed to be known as remedial teaching since holiday tuition was outlawed in Kenya.

From the table above it can generally be observed that the respondents (mean = 1.5262) rated the variable salary/wages highly, as a big number of respondents disagree to all these sub variables.

The respondents agreed that teaching learning facilities in most schools in Borabu District are very much inadequate. The figure above shows the trend and the rate at which the sub variables tested moves towards the fourth scale 'agree,' from 'disagree.' It is shocking to learn that most of the respondents agreed that classrooms, libraries and laboratories in their schools (mean $=3.352$ ) are hardly enough. This being the major facilities in many of the secondary schools in Borabu District (since many of them are day schools) used in the day to day process of teaching, teachers are expected to have a hilarious task in curriculum delivery (Table 6).

When interviewing the principals on how they made up with the inadequate resources and materials for learning, most of them were in agreement that at times they 
Table 6. Teachers' Perception on School facilities.

\begin{tabular}{|c|c|c|c|c|c|}
\hline & & & & Mean & Std. Deviation \\
\hline \multicolumn{4}{|c|}{ I feel the means and resources required to do my job properly are inadequate. } & 3.0374 & 1.06442 \\
\hline \multicolumn{4}{|c|}{$\begin{array}{l}\text { Am given school related duties without adequate resources and materials to } \\
\text { carry them out. }\end{array}$} & 3.1016 & 1.00822 \\
\hline \multicolumn{4}{|c|}{ I feel there aren't enough classrooms, libraries and laboratories in my school. } & 3.3529 & 0.99111 \\
\hline \multicolumn{4}{|c|}{ I feel that learning facilities in my school are not up to standard. } & 3.0107 & 1.08751 \\
\hline & $\mathrm{N}$ & Minimum & Maximum & Mean & Std. Deviation \\
\hline School Facilities & 187 & 1.00 & 4.00 & 1.8743 & 0.78903 \\
\hline Valid N (listwise) & 187 & & & & \\
\hline
\end{tabular}

use even their personal funds to purchase the needed items to be refunded later. [21] in his research wondered if there was any other professional world over where workers are required to update their skills frequently at their own expenses like that of teaching. It happens that at times teachers are required to compensate for lack of school resources by paying for their own classroom materials [22].

While assessing what caused teacher burnout, [21] observed that it is ironic that the best teachers are the most susceptible to burnout. Their unrelenting dedication to students can lead them to take on too many tasks, which end up drawing their creative energy.

This study further purposed to find out if the teachers were contented with the extra roles that they were expected to perform besides their professional duties. Data is presented in Table 7.

Many of the respondents agreed that they cared for their student academic performances besides their professional duties. Majority of the respondents agreed that they cared for their students' academic performance and they were patient when students had trouble with learning. A fairly big number of the respondents (mean $=3.6257$ ) agreed that they would always get their students to believe they could do well in school, and could help their students to value learning (mean = 3.7005). It was further found that many of the teachers (mean $=3.5615$ ) used a variety of assessment strategies for their students, and that they felt they were expected to act as surrogate parents in assisting the children to do well (mean $=3.5294$ ).

A number of teachers felt that their expectations when entering the job were conflicting with the teaching reality they faced. This meant that though they were comfortably performing those duties, down in their hearts they did not expect all that when joining the teaching profession.

\section{Conclusions and Recommendations}

The study found out that the aspect of the principal's important communicating information to the teachers in time was average, but needed improvement. Though they are averagely rated, it shows that most of the Head teachers in Borabu Public Secondary 
Table 7. Teacher's perception on role expectation.

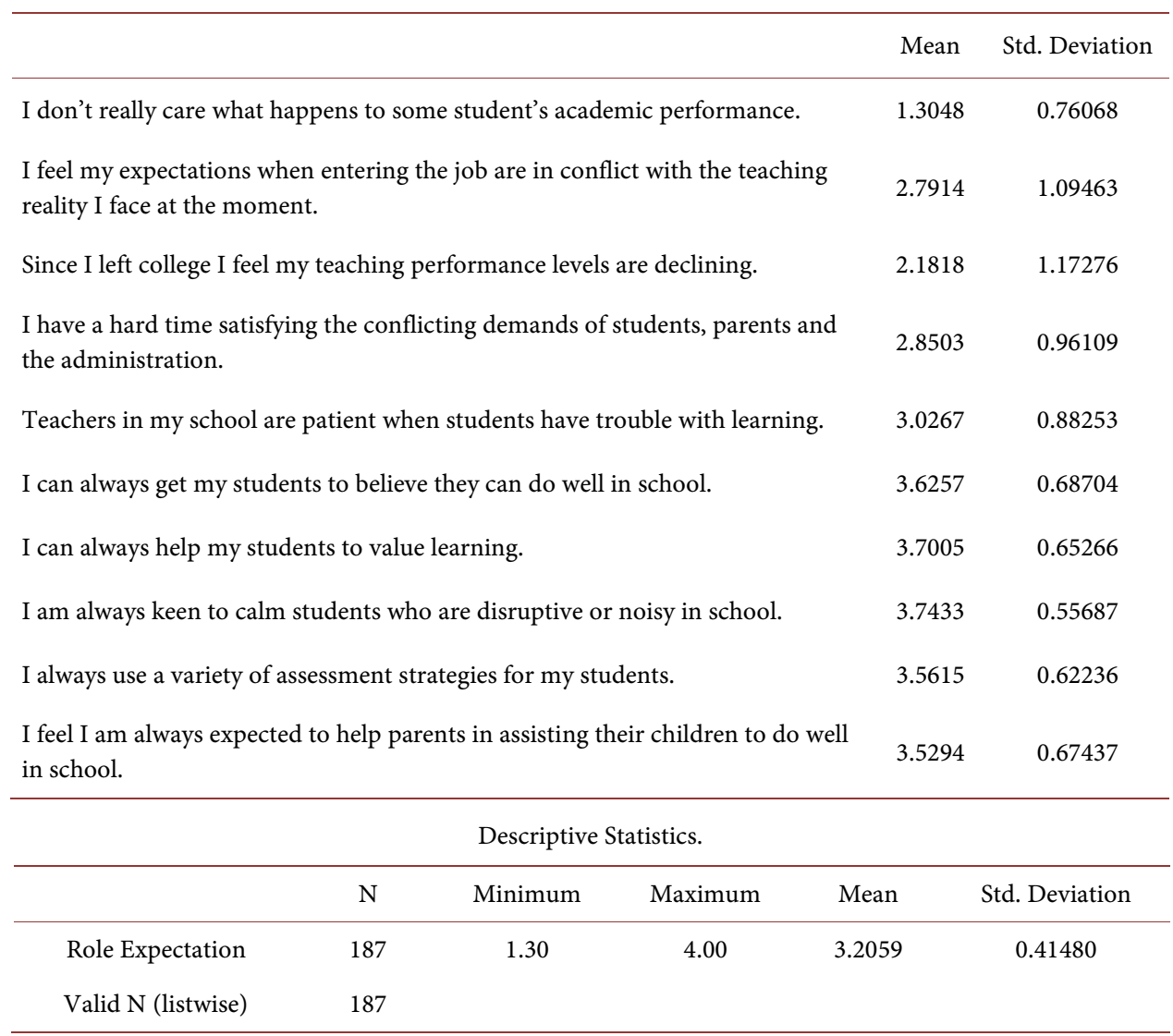

schools do communicate important issues with their teachers in time. But it also indicates that there are some principals who need to improve in the way and speed at which information is relayed to their teachers.

The study also found out that most principals do not involve their teachers in planning school activities and functions. On the climate set by the principals in their schools, more than a half of the respondents agreed that their schools had positive environment to work in. The study also established that some teachers are overloaded and there is need to hire more teachers to lessen this burden. Staff development is a key area in any work environment. This study found out that schools are not motivating teachers to develop themselves; therefore schools should be ready to create space for teachers' development so that they can update their teaching skills. In order for students to perform well in their academics, their discipline should be maintained. Teachers should work together with parents to encourage students to put effort and minimize disciplinary cases. Teachers' salaries should be improved as a factor in motivating them. Learning and teaching resources play a major role in promoting academic performance which suggests that unless schools are equipped with the necessary facilities, learning may not be successful.

Further research could look at why teachers have consistently complained of low salaries yet governments continue down playing this need. 


\section{References}

[1] Ng'eno, G. (2007) Causes of Teacher Burnout among Primary School Teachers within Kericho Municipality, Kenya. Journal of Technology and Education in Nigeria, 22, 9-18.

[2] Harrington, I. (2013) School-Based Learning for Individual Diversity in Education: The SLIDE Project. Journal of Education and Training Studies, 1, 25-30. https://doi.org/10.11114/jets.v1i2.112

[3] Imo, E.U., Oswald, E.A. and Inyang, N.V. (2013) Staff Development Programmes and Secondary School Teachers' Job Performance in Uyo Metropolis, Nigeria. Journal of Education and Practice, 4, 217-222.

[4] Weick, K.E. (1995) Sense Making in Organizations. Sage, Thousand Oaks.

[5] Byrne, B.M. (1999) The Nomological Network of Teacher Burnout: A Literature Review and Empirically Validated Model. In: Vandenberghe, R. and Huberman, A.M., Eds., Understanding and Preventing Teacher Burnout: A Sourcebook of International Research and Practice. Cambridge College Press, Cambridge, 15-37. https://doi.org/10.1017/CBO9780511527784.003

[6] Conoley, J.C. and Goldstein, A.P. (2004) School Violence Intervention: A Practical Handbook. 2nd Edition, Guilford, New York.

[7] Dworkin, G.A. (1987) Teacher Burnout in the Public Schools: Structural Causes and Consequences for Children. State University of New York Press, Albany.

[8] Maslach, C. and Pines, A. (1977) The Burnout Syndrome in the Daycare Setting. Child Care Quarterly, 62, 100-113. https://doi.org/10.1007/BF01554696

[9] Frazier, L.M. (2002) Deteriorating School Facilities and Student Learning. Eric Digest, Number 82. http://ericae.net/edo/ED356564.htm

[10] Lyons, J.B. (2001) Do School Facilities Really Impact a Child's Education? http://sdpl.coe.uga.edu/articlesandpapers/lyons.html

[11] Buckley, J., Schneider, M. and Shang, Y. (2004) LAUSD School Facilities and Academic Performance. Washington DC.

[12] Rizzo, J.R., House, R.J. and Lirtzman, S.I. (1970) Role Conflict and Ambiguity in Complex Organizations. Administrative Science Quarterly, 15, 150-163. https://doi.org/10.2307/2391486

[13] Haberman, M. (1995) Burnout in Teaching Careers. European Education, 25, 477.

[14] Mugenda, O.M. and Mugenda, A.G. (2003) Research Methods, Quantitative and Qualitative Approaches. ACT, Nairobi.

[15] Role, E.M. (2008) Handbook of Social and Educational Research Methods. University of Eastern Africa, Baraton, Compilation on Notes.

[16] Sergiovanni, T.J. (2009) Building Community in Schools. Jossey-Bass, San Francisco.

[17] Okumbe, J.A. (1999) Educational Management: Theory and Practice. University of Nairobi Press, Nairobi.

[18] Purkey, W.W. (1970) Self-Concept and School Achievement. Prentice-Hall, Englewood Cliffs.

[19] Price, J.L. (1977) The Study of Turnover. Iowa State University Press, Ames.

[20] Lortie, C.D. (1975) School Teacher: A Sociological Study. University of Chicago Press, Chicago.

[21] Park. (2002) Battling Teacher Burnout. Focal/Points 20. 
http://www.publication.org/downloard

[22] Ann, M.C. (2002) The Cooperative Classroom: Empowering Learning. Prentice Hall, Upper Saddle River.

Submit or recommend next manuscript to OALib Journal and we will provide best service for you:

- Publication frequency: Monthly

- 9 subject areas of science, technology and medicine

- Fair and rigorous peer-review system

- Fast publication process

- Article promotion in various social networking sites (LinkedIn, Facebook, Twitter, etc.)

- Maximum dissemination of your research work

Submit Your Paper Online: Click Here to Submit

Or Contact service@oalib.com 